DOI: https://doi.org/10.46370/sajfte.2020.v06i01.02

\title{
Milk improves cholesterol homoeostasis by protecting liver against oxidative damage in hypercholesterolemic rats
}

\author{
Sunita Meena*1 ${ }^{1}$, udhisthir Singh Rajput ${ }^{1}$, Rajan Sharma ${ }^{2}$ and Raghvendar Singh ${ }^{3}$ \\ ${ }^{1}$ Animal Biochemistry Division, National Dairy Research Institute, Karnal (Haryana)-132001, India \\ ${ }^{2}$ Dairy Chemistry Division, National Dairy Research Institute, Karnal (Haryana)-132001, India \\ ${ }^{3}$ National Research Centre on Camel, Bikaner (Rajasthan) 334001, India \\ *Email: sunitameena1188@gmail.com
}

\begin{abstract}
The study was designed to evaluate relative effectiveness of cow, buffalo, goat and camel milk in maintaining cholesterol homeostasis in experimental rats fed on cholesterol enriched diet (CED) containing $1.5 \%$ cholesterol and $0.375 \% \mathrm{Na}$ cholate. CED without milk led to disturbance in cholesterol homeostasis and oxidative damage in liver. Feeding of milk (3\% fat) for 12 weeks resulted in significant decrease in plasma TC, TGs, VLDL-C, LDL-C and atherogenic index (AI) and increase in HDL-C. Also, milk-feeding decreased the cholesterol deposition in aorta and liver with simultaneous increase in cholesterol excretion in feces. Effectiveness of goat and camel milk in maintaining cholesterol homeostasis was higher than cow or buffalo milk. Milk in general protected liver against oxidative damage occurred on feeding of CED and this can partly be ascribed to enhanced activity of anti-oxidant enzymes.
\end{abstract}

Key word: Atherogenic index, cholesterol, homoeostasis, hypercholesterolemic, oxidative.

Paper cited: Meena, S., Rajput, Y.S., Sharma, R. and Singh, R. (2020). Milk improves cholesterol homoeostasis by protecting liver against oxidative damage in hypercholesterolemic rats. South Asian Journal of Food Technology and Environment, 6(1): 885-893.

\section{Introduction}

Cardiovascular disease (CVD) is one of the major health problem concerns all over the world. Risk factors for cardiovascular disease are many but hypercholesterolemia is considered as a strong risk factor for CVD. Pharmacological interventions such as statins, niacin, fibrates, thiazolidinediones, glitazers, cholesterol ester transfer protein inhibitors, acyl-coenzyme A cholesterol acyltransferase inhibitors are in use for reducing the risk of CVD. Drugs are used to save the life, alleviate the symptoms and relieve the pain but their continuous use is more or less related with side effects. To overcome this issue, other non-pharmacological interventions in the treatment of such diseases are now being focused. Therefore, drugs are now being prescribed in combination with appropriate diet to reduce the risk of cardiovascular complications.

Milk is complex biological fluid comprising of fat, protein, lactose, minerals, vitamins and many minor components. Composition of milk from different species is not identical and even may differ significantly for certain ingredient. Camel milk lacks $\beta$ lactoglobulin and $\beta$-casein which are main causative agents of allergy in bovine milk (Nikkah, 2011; Shabo and Yagil, 2005). Camel 
milk contains high content of zinc, manganese, copper and Vitamins C, E and A (Al-Awadi and Srikumar, 2001; Al-Ayadhi and Elamin, 2013; Nikkah 2011) and thus it possesses better antioxidative activity. Total antioxidant capacity (TAC) of goat milk differs from breed to breed and TAC of milk from Prisca breed of goat has been reported to be higher than cow or donkey milk (Simos et al., 2011). Selenium is an integral component of glutathione peroxidase, an enzyme responsible for peroxide detoxification, is about $50 \%$ higher in human and goat milk as compared to cow milk (Debski et al., 1987). Goat milk protein on its hydrolysis by proteases enhances radical scavenging activity and iron chelation capacity (Gobba et al., 2014). The size of fat globule in milk of camel and goat is relatively lower than cow milk fat globule and is easily digested (Meena et al., 2014). Camel milk consumption is recommended to treat jaundice, asthma, anemia, pile, tuberculosis, diabetes, autism (Shabo and Yagil, 2005) and autoimmune disease (Nikkah, 2011). Short chain fatty acids, a component of milk fat, are known to enhance immune functions, lower heart disease and exhibits antimicrobial activity (Conesa et al., 2008; El-Agamy et al., 2009; Khay et al., 2011). Also, monounsaturated fatty acids, also a part of milk fat, can lower LDL-cholesterol and total cholesterol. Saturated fatty acid, which is abundantly present in milk fat, exhibits hypercholesterolemic effect (Bravo et al.,. 1998). Preliminary results from human subjects suggest that camel milk reduces blood glucose, $\mathrm{HbA}_{1 \mathrm{c}}$ levels and insulin requirement in diabetic human patients (Agrawal et al., 2007; Kotb-El-Sayed et al., 2011). Also, cow milk can reverse the atherosclerotic process in experimental rabbits (Aggarwal and Kansal, 1992). It is not clear whether all milks can exert antihypercholesterolemic effect. In present work, cholesterol lowering potential of goat, camel, cow and buffalo milk is assessed in cholesterol fed experimental rats and results are presented here.

\section{Materials and methods}

\section{Animals}

Forty eight male albino rats of Wistar strain used in the study were obtained from Small Animal House of National Dairy Research Institute, Karnal, Haryana, India. The animals were 8 weeks old and were of similar body weight $(200-250 \mathrm{~g})$. Rats were housed in a polycarbonate cages at a temperature $\left(24 \pm 2^{\circ} \mathrm{C}\right)$ and relative humidity $(55 \pm 10 \%)$, with a $12: 12 \mathrm{~h}$ light-dark cycle. The study was approved and maintained in accordance with the animal ethics committee of the Institute.

\section{Diet}

The components of the standard diet (SD) and cholesterol enriched diet (CED) are enlisted in the Table 1. Mineral and vitamin mixture were prepared and mixed according to the AOAC (1990). After acclimatization for one week on standard diet, the rats were divided into 6 groups and each group consists of 8 rats and fed as follows:

1. Control group: SD

2. CED group: CED

3. CED + Goat group: CED + Goat milk (3\% fat)

4. CED + Camel group: CED + Camel milk (3\% fat)

5. CED + Cow group: CED + Cow milk (3\% fat)

6. CED + Buffalo group: CED + Buffalo milk (3\% fat)

Goat, cow and buffalo milk was obtained from cattle yard of the Institute and camel milk was obtained from National Research Centre on Camel, Bikaner, India. Fat percentage of milk was adjusted to $3 \%$ and $25 \mathrm{~mL}$ milk per rat per day was given and diet was provided ad libitum. The study was conducted for three months. 
Milk improves cholesterol homoeostasis by protecting liver against oxidative damage in hypercholesterolemic rats

\section{Blood Sample}

Animals were sacrificed by cervical dislocation and blood was collected through heart puncture in EDTA coated vaccutainers. Blood was then transferred in to centrifuge tubes and centrifuged at $1600 \times \mathrm{g}$ for $10 \mathrm{~min}$ at $4^{\circ} \mathrm{C}$. Plasma was separated and total cholesterol (TC), triglycerides (TGs) and high density lipoproteincholesterol (HDL-C) were estimated using kits (Span diagnostics Ltd. Surat, India). Low density lipoprotein cholesterol (LDL-C), very low density lipoprotein cholesterol (VLDLC) and atherogenic index (AI) were calculated using Friedewald's equation (Friedewald et al., 1972).

\section{Cholesterol in liver, aorta and feces}

Liver and aorta were excised, washed with $0.2 \mathrm{M}$ phosphate buffer saline ( $\mathrm{pH} 7.4)$. The liver tissue, aorta and feces were homogenized in chloroform : methanol (2:1) mixture, cholesterol was extracted in accordance to the method described by Folch and coworkers (1957) and was estimated using kit (Span diagnostics Ltd. Surat, India).

\section{Antioxidative enzyme activity}

Activity of catalase, glutathione peroxidase (GPx) and superoxide dismutase (SOD) in liver homogenate and RBC lysate were determined by spectrophotometric methods. Catalase activity was determined by the rate of decomposition of $\mathrm{H}_{2} \mathrm{O}_{2}$ at $240 \mathrm{~nm}$ (Aebi, 1984). The catalase activity was calculated using extinction coefficient $0.0394 \mathrm{mM}^{-1} \mathrm{~cm}^{-1}$ and expressed as $\mu$ moles of $\mathrm{H}_{2} \mathrm{O}_{2}$ consumed $/ \mathrm{mg} / \mathrm{min}$. GPx activity was assayed at $340 \mathrm{~nm}$ by utilizing excess of glutathione reductase that couples the rate of oxidation of NADPH to reaction of the peroxidase with $\mathrm{H}_{2} \mathrm{O}_{2}$ and glutathione (reduced) (Paglia and Valentine, 1967).The enzyme activity was calculated using extinction coefficient 6.22 $\mathrm{mM}^{-1} \mathrm{~cm}^{-1}$, where unit enzyme activity is one mmole of NADPH oxidized per min. One unit of SOD was defined as the amount of enzyme that inhibits the auto-oxidation of pyrogallol by $50 \%$ at 420nm (Marklund and Marklund, 1974).

Estimation of thiobarbituric acid reactive substances (TBARS) and Protein Carbonyls (PCs)

TBARS and PCs were determined in liver tissue homogenate and plasma. Lipid peroxidation in liver and plasma was estimated by the method of Nichans and Samuelson (1968). The tissue homogenate was prepared in phosphate buffer (50 mM, pH 7.4). To one $\mathrm{mL}$ of tissue homogenate or plasma, $2 \mathrm{~mL}$ of TCATBA-HCl (5\% trichloroacetic acid, $0.375 \%$ thiobarbituric acid and $0.25 \mathrm{~N} \mathrm{HCl}$ ) reagent in 1:1:1 ratio was added, mixed thoroughly and boiled for $15 \mathrm{~min}$. The color developed in the supernatant obtained after centrifugation was measured spectrophotometrically at $535 \mathrm{~nm}$. Standard of malondialdehyde (MDA) in the range of 8-40 nmoles was prepared by carrying out overnight digestion of different concentrations of 1,1,3,3-tetraethoxypropane in presence of $0.2 \mathrm{~N} \mathrm{HCl}$ and expressed as nmoles of MDA per mg protein. PCs were measured according to the method of Levine et al., (1990) and modified by Bejma and Ji (1999). Tissue homogenate was prepared in potassium phosphate buffer $(5 \mathrm{mM}, \mathrm{pH} 7.4)$ containing $0.1 \%$ Triton X-100 containing aprotonin $(1 \mathrm{mg} / \mathrm{L})$, leupeptin $(1 \mathrm{mg} / \mathrm{L})$, pepstatin A $(0.35 \mathrm{mg} / \mathrm{L})$ PMSF $(85 \mathrm{mg} / \mathrm{L})$. After centrifugation, $10 \%$ streptomycin sulphate was added to supernatant (and plasma) at the final concentration of $1 \%$ and vortexed. Subsequently, trichloroacetic acid (20\%) was added to precipitate the proteins. To the precipitate, dinitrophenyl hydrazine (DNPH) was added and allowed to stand for $1 \mathrm{~h}$ in dark. Washing was done with ethanol:ethyl acetate (1:1) to remove excess of DNPH and the resulting pellet was suspended in $6 \mathrm{M}$ guanidine HCl. PCs as 2,4-dinitrophenylhydrazonecarbonyl adduct were measured spectrophotometrically at $360 \mathrm{~nm}$ and the content of carbonyl was calculated using a molar 
absorption coefficient of DNPH, $22 \mathrm{mM}^{-1} \mathrm{~cm}^{-1}$ and expressed as nmoles of dinitrophenylhydrazone carbonyl adduct per mg protein.

\section{Protein estimation}

Protein was estimated in tissue homogenate and plasma by Lowry's method (Lowry et al., 1951) using bovine serum albumin as standard. Hemoglobin in RBC lysate was determined by Drabkin cyanmethemoglobin method (Drabkin, 1950).

\section{Statistical analysis}

All the results are expressed as mean \pm SEM. Using GraphPad PRISM version 5.0 statistical software package analysis of variance was performed and differences between the groups were tested using Tukey post-hoc test.

\section{Results and Discussion}

\section{Body Weight}

Feeding of CED resulted in increase in body weight from $318.4 \pm 5.855 \mathrm{~g}$ to $380.0 \pm$ $4.884 \mathrm{~g}$ over the period of 90 days experimental period (Table 2). There was no further increase in body weight on feeding of goat or camel milk. However, body weight was significantly higher in cow and buffalo milk fed groups as compared to CED group at the end of experimental period.

\section{Plasma Lipids, Atherogenic Index, Cholesterol deposition in aorta}

In CED group, plasma TC, TGs, VLDL$\mathrm{C}$, LDL-C level and atherogenic index increased and HDL-C level decreased significantly as compared to control. Upon administration of milk along with CED, the plasma TC, TGs, VLDL-C and LDL-C decreased and HDL-C level increased significantly as compared to $\mathrm{CED}$ group (Table 2). Atherogenic index, which takes in to account concentration of these lipids, is lower in all milk fed groups than in CED group.

\section{Cholesterollevel in aorta, liverand feces}

Feeding of goat milk, camel milk, cow milk and buffalo milk to rats fed on CED resulted in reduction of cholesterol deposition in aorta by $45 \%, 51 \%, 41 \%$ and $53 \%$ respectively (Table 3 ).
Cholesterol content in liver in milk fed group was also lower and effectiveness of milk was in order of (goat milk, camel milk) > cow milk > buffalo milk. Similarly, cholesterol content in feces in milk fed group was higher than CED group and effectiveness of milk was in order of (goat milk, camel milk) > cow milk > buffalo milk. Thus, there is striking resemblance in between extent of excretion of cholesterol through feces and extent of deposition in liver. The results suggest that enhanced excretion of cholesterol is linked with cholesterol deposition in liver.

\section{Antioxidant enzyme activity and Oxidative damaged products}

The activity of catalase, GPx and SOD was measured in liver and $\mathrm{RBC}$ in rats fed on normal diet, CED and milk supplemented with CED. Feeding of cholesterol enriched diet resulted in decrease incatalase, GPx and SOD activity in liver as well as in RBC indicating that these cells will find difficulty in overcoming oxidative stress. Feeding of goat milk fully restored catalase activity in liver as well as in RBC and activity of other enzymes also significantly enhanced (Table 4). Camel milk restored activity of GPx in liver and except SOD in $\mathrm{RBC}$, also significantly enhanced activity of these enzymes. Effectiveness of cow milk viz a viz goat or camel milk was poor in comparative terms. Buffalo milk was least effective in enhancing reduced activity of anti-oxidant enzymes in liver and RBC (Table 4).

Cholesterol enriched diet resulted in 3.4 and 3.8 fold increase in TBARS and PCs in liver while in plasma, increase in TBARS and PCs was 1.74 and 2.38 fold respectively (Table 5). The results suggest that liver which plays central role in cholesterol homeostasis, is damaged in hypercholesterolemic rats. In general, milkfeeding resulted in lower production of TBARS and PCs. Effectiveness of goat and camel milk was similar and was better than cow milk. Buffalo milk was least effective (Table 5). 
Milk improves cholesterol homoeostasis by protecting liver against oxidative damage in hypercholesterolemic rats

Table 1: Composition of Standard and Cholesterol Enriched Diet

\begin{tabular}{|c|l|c|c|}
\hline S. No. & Component $(\mathbf{g} / \mathbf{1 0 0 g}$ of diet) & Standard Diet & Cholesterol Enriched Diet \\
\hline 1. & Starch & 53.200 & 51.325 \\
2. & Casein & 20.000 & 20.000 \\
3. & Sucrose & 10.000 & 10.000 \\
4. & Soybean oil & 7.000 & 7.000 \\
5. & Cellulose & 5.000 & 5.000 \\
6. & Vitamin mixture & 1.000 & 1.000 \\
7. & Mineral mixture & 3.500 & 3.500 \\
8. & Methionine & 0.300 & 0.300 \\
9. & Cholesterol & -- & 1.500 \\
10. & Sodium cholate & -- & 0.375 \\
\hline
\end{tabular}

Table 2: Body weight and Lipid levels in plasma

\begin{tabular}{|c|c|c|c|c|c|c|}
\hline Parameters & Control & CED & CED+ Goat & $\begin{array}{l}\text { CED+ } \\
\text { Camel }\end{array}$ & $\begin{array}{l}\text { CED+ } \\
\text { Cow }\end{array}$ & $\begin{array}{c}\text { CED+ } \\
\text { Buffalo }\end{array}$ \\
\hline $\begin{array}{l}\text { Body weight } \\
\text { (g) - } 0 \text { day }\end{array}$ & $\begin{array}{l}202.4 \pm \\
3.693^{\mathrm{a}}\end{array}$ & $\begin{array}{l}198.1 \pm \\
5.400^{\mathrm{a}}\end{array}$ & $\begin{array}{c}205.3 \pm \\
4.362^{\mathrm{a}}\end{array}$ & $\begin{array}{c}201.9 \pm \\
4.340^{\mathrm{a}}\end{array}$ & $\begin{array}{c}202.6 \pm \\
5.092^{\mathrm{a}}\end{array}$ & $\begin{array}{c}200.0 \pm \\
4.309^{\mathrm{a}}\end{array}$ \\
\hline Body weight & $318.4 \pm$ & $380.0 \pm$ & $369.4 \pm$ & $358.5 \pm$ & $401.1 \pm$ & $398.8 \pm$ \\
\hline (g) - 90 day & $5.855^{\mathrm{a}}$ & $4.884^{\mathrm{b}}$ & $5.032^{\mathrm{b}}$ & $4.610^{\mathrm{b}}$ & $5.658^{\mathrm{d}}$ & $5.467^{\mathrm{d}}$ \\
\hline TC & $79.77 \pm$ & $79.48 \pm$ & $76.43 \pm$ & $75.10 \pm$ & $74.24 \pm$ & $77.48 \pm$ \\
\hline $\begin{array}{l}(\mathrm{mgaL})-0 \\
\mathrm{TC}\end{array}$ & $\begin{array}{l}0 . / 89 \\
84.90 \pm\end{array}$ & $\begin{array}{c}6.619^{n} \\
302.3 \pm\end{array}$ & $\begin{array}{l}7.423^{\circ} \\
175.9 \pm\end{array}$ & $\begin{array}{l}7.546^{\circ} \\
145.8 \pm\end{array}$ & $\begin{array}{c}0.588 \\
141.1 \pm\end{array}$ & $132.0 \pm$ \\
\hline$\left(m g ~ d L^{-1}\right)-90$ day & $3.498^{\mathrm{a}}$ & $5.324^{\mathrm{b}}$ & $5.360^{\mathrm{c}}$ & $3.598^{\mathrm{d}}$ & $4.902^{\mathrm{d}}$ & $3.518^{\mathrm{d}}$ \\
\hline HDL-C & $34.39 \pm$ & 37.72 & $34.68 \pm$ & $32.62 \pm$ & $33.37 \pm$ & 35.13 \\
\hline$\left(\mathrm{mg} \mathrm{dL}^{-1}\right)-0$ day & $2.441^{\mathrm{a}}$ & $\pm 2.087^{\mathrm{a}}$ & $2.130^{\mathrm{a}}$ & $2.275^{\mathrm{a}}$ & $2.492^{\mathrm{a}}$ & $\pm 1.937^{\mathrm{a}}$ \\
\hline HDL-C & $32.32 \pm$ & $17.03 \pm$ & $28.90 \pm$ & $28.07 \pm$ & $23.00 \pm$ & $28.07 \pm$ \\
\hline$\left(m g \mathrm{dL}^{-1}\right)-90$ day & $0.801^{\mathrm{a}}$ & $0.922^{\mathrm{b}}$ & $0.869^{\mathrm{ac}}$ & $1.083^{\mathrm{c}}$ & $0.911^{\mathrm{d}}$ & $1.186^{\mathrm{c}}$ \\
\hline TG & $81.85 \pm$ & $79.94 \pm$ & $83.28 \pm$ & $80.89 \pm$ & $91.08 \pm$ & $82.48 \pm$ \\
\hline$\left(m g d L^{-1}\right)$ - 0 day & $6.512^{\mathrm{a}}$ & $5.841^{\mathrm{a}}$ & $8.374^{\mathrm{a}}$ & $8.927^{\mathrm{a}}$ & $9.820^{\mathrm{a}}$ & $7.132^{\mathrm{a}}$ \\
\hline TG & $111.3 \pm$ & $164.8 \pm$ & $114.8 \pm$ & $85.65 \pm$ & $81.13 \pm$ & $81.94 \pm$ \\
\hline$\left(m g d^{-1}\right)$ - 90 day & $3.838^{\mathrm{a}}$ & $5.380^{\mathrm{b}}$ & $6.101^{\mathrm{a}}$ & $5.039^{c}$ & $4.303^{c}$ & $3.970^{\mathrm{c}}$ \\
\hline VLDL-C & $16.37 \pm$ & $15.99 \pm$ & $16.66 \pm$ & $16.18 \pm$ & $18.22 \pm$ & $16.50 \pm$ \\
\hline$\left(\mathrm{mg} \mathrm{dL}^{-1}\right)-0$ day & $1.302^{\mathrm{a}}$ & $1.168^{\mathrm{a}}$ & $1.675^{\mathrm{a}}$ & $1.785^{\mathrm{a}}$ & $1.964^{\mathrm{a}}$ & $1.426^{\mathrm{a}}$ \\
\hline VLDL-C & $22.26 \pm$ & $32.97 \pm$ & $22.97 \pm$ & $17.13 \pm$ & $16.23 \pm$ & $16.39 \pm$ \\
\hline$\left(m g ~ d L^{-1}\right)$ - 90 day & $0.767^{\mathrm{a}}$ & $1.076^{\mathrm{b}}$ & $1.220^{\mathrm{a}}$ & $1.008^{\mathrm{c}}$ & $0.860^{\mathrm{c}}$ & $0.793^{\mathrm{c}}$ \\
\hline LDL-C & $29.01 \pm$ & $25.78 \pm$ & $25.10 \pm$ & $26.29 \pm$ & $22.65 \pm$ & $25.85 \pm$ \\
\hline$\left(m g \mathrm{dL}^{-1}\right)$ - 0 day & $4.811^{\mathrm{a}}$ & $4.243^{\mathrm{a}}$ & $4.302^{\mathrm{a}}$ & $5.618^{\mathrm{a}}$ & $3.035^{\mathrm{a}}$ & $4.287^{\mathrm{a}}$ \\
\hline LDL-C & $30.32 \pm$ & $252.3 \pm$ & $124.1 \pm$ & $100.6 \pm$ & $101.9 \pm$ & $87.53 \pm$ \\
\hline$\left(\mathrm{mg} \mathrm{dL}^{-1}\right)-90$ day & $3.659^{\mathrm{a}}$ & $6.144^{\mathrm{b}}$ & $6.112^{\mathrm{c}}$ & $3.677^{\mathrm{d}}$ & $5.378^{\bar{d}}$ & $3.057^{\mathrm{d}}$ \\
\hline AI- 0 day & $1.324 \pm$ & $1.098 \pm$ & $1.179 \pm$ & $1.280 \pm$ & $1.213 \pm$ & $1.192 \pm$ \\
\hline & $0.120^{\mathrm{a}}$ & $0.106^{\mathrm{a}}$ & $0.106^{\mathrm{a}}$ & $0.119^{\mathrm{a}}$ & $0.055^{\mathrm{a}}$ & $0.089^{\mathrm{a}}$ \\
\hline AI- 90 day & $\begin{array}{c}1.639 \pm \\
0.127^{\mathrm{a}}\end{array}$ & $\begin{array}{c}17.11 \pm \\
1.025^{\mathrm{b}}\end{array}$ & $\begin{array}{l}5.145 \pm \\
0.315^{c}\end{array}$ & $\begin{array}{r}4.244 \pm \\
0.216^{\mathrm{c}}\end{array}$ & $\begin{array}{r}5.224 \pm \\
0.365^{c}\end{array}$ & $\begin{array}{l}3.741 \pm \\
0.166^{\mathrm{ac}}\end{array}$ \\
\hline
\end{tabular}

Values are mean \pm SEM for $\mathrm{n}=8$.Similar superscript alphabets in row indicate non-significant differences $(\mathrm{P} \geq 0.05)$ at defined day. Dissimilar superscript alphabets in row indicate significant differences $(\mathrm{P}<0.05)$ at defined day. 
Table 3: Cholesterol in aorta, liver and feces

\begin{tabular}{|c|c|c|c|c|c|c|}
\hline $\begin{array}{c}\text { Cholesterol } \\
\left(\mathbf{m g ~ g}^{-1}\right)\end{array}$ & Control & CED & $\begin{array}{c}\text { CED+ } \\
\text { Goat }\end{array}$ & $\begin{array}{c}\text { CED+ } \\
\text { Camel }\end{array}$ & $\begin{array}{c}\text { CED+ } \\
\text { Cow }\end{array}$ & $\begin{array}{c}\text { CED+ } \\
\text { Buffalo }\end{array}$ \\
\hline Aorta & $0.7593 \pm$ & $3.130 \pm$ & $1.731 \pm$ & $1.546 \pm$ & $1.843 \pm$ & $1.491 \pm$ \\
& $0.038 \mathrm{a}$ & $0.179 \mathrm{~b}$ & $0.050 \mathrm{c}$ & $0.056 \mathrm{c}$ & $0.074 \mathrm{c}$ & $0.082 \mathrm{c}$ \\
Liver & $3.321 \pm$ & $19.74 \pm$ & $6.908 \pm$ & $7.748 \pm$ & $11.48 \pm$ & $15.68 \pm$ \\
& $0.245 \mathrm{a}$ & $0.326 \mathrm{~b}$ & $0.201 \mathrm{e}$ & $0.302 \mathrm{e}$ & $0.391 \mathrm{~d}$ & $0.319 \mathrm{c}$ \\
Feces & $6.314 \pm$ & $21.88 \pm$ & $34.06 \pm$ & $31.69 \pm$ & $27.04 \pm$ & $24.95 \pm$ \\
& $0.514 \mathrm{a}$ & $0.575 \mathrm{~b}$ & $0.707 \mathrm{~d}$ & $0.609 \mathrm{~d}$ & $0.714 \mathrm{c}$ & $0.461 \mathrm{c}$ \\
\hline
\end{tabular}

Values are mean \pm SEM for $\mathrm{n}=8$. Similar superscript alphabets in row indicate non-significant differences $(\mathrm{P} \geq 0.05)$ at $90^{\text {th }}$ day. Dissimilar superscript alphabets in row indicate significant differences $(\mathrm{P}<0.05)$ at $90^{\text {th }}$ day.

Table 4: Antioxidative enzymes activity in liver and RBC

\begin{tabular}{|l|c|c|c|c|c|c|}
\hline $\begin{array}{c}\text { Enzyme activity } \\
\left(\mathbf{U ~ m g ~}^{-1} \mathbf{m i n}^{-1}\right)\end{array}$ & Control & CED & $\begin{array}{c}\text { CED+ } \\
\text { Goat }\end{array}$ & $\begin{array}{c}\text { CED+ } \\
\text { Camel }\end{array}$ & $\begin{array}{c}\text { CED+ } \\
\text { Cow }\end{array}$ & $\begin{array}{c}\text { CED+ } \\
\text { Buffalo }\end{array}$ \\
\hline Catalase in liver & $525.3 \pm$ & $299.3 \pm$ & $500.2 \pm$ & $453.9 \pm$ & $424.8 \pm$ & $404.8 \pm$ \\
& $10.570^{\mathrm{a}}$ & $14.730^{\mathrm{b}}$ & $10.120^{\mathrm{ad}}$ & $18.140^{\mathrm{cd}}$ & $14.070^{\mathrm{c}}$ & $16.370^{\mathrm{c}}$ \\
GPx in liver & $11.190 \pm$ & $8.1050 \pm$ & $10.560 \pm$ & $10.740 \pm$ & $8.460 \pm$ & $8.674 \pm$ \\
& $0.404^{\mathrm{a}}$ & $0.379^{\mathrm{b}}$ & $0.485^{\mathrm{a}}$ & $0.399^{\mathrm{a}}$ & $0.404^{\mathrm{b}}$ & $0.571^{\mathrm{b}}$ \\
SOD in liver & $42.15 \pm$ & $26.09 \pm$ & $36.38 \pm$ & $33.79 \pm$ & $30.58 \pm$ & $30.33 \pm$ \\
& $1.188^{\mathrm{a}}$ & $1.256^{\mathrm{b}}$ & $1.275^{\mathrm{c}}$ & $1.185^{\mathrm{cd}}$ & $0.951^{\mathrm{bd}}$ & $1.365^{\mathrm{bd}}$ \\
Catalase in RBCs & $73.64 \pm$ & $52.52 \pm$ & $69.14 \pm$ & $64.77 \pm$ & $61.92 \pm$ & $59.76 \pm$ \\
& $1.124^{\mathrm{a}}$ & $1.721^{\mathrm{b}}$ & $1.907^{\mathrm{ac}}$ & $1.365^{\mathrm{cd}}$ & $2.176^{\mathrm{ce}}$ & $1.927^{\mathrm{bde}}$ \\
GPx in RBCs & $6.255 \pm$ & $3.406 \pm$ & $5.360 \pm$ & $5.004 \pm$ & $4.613 \pm$ & $4.244 \pm$ \\
& $0.207^{\mathrm{a}}$ & $0.240^{\mathrm{b}}$ & $0.274^{\mathrm{c}}$ & $0.171^{\mathrm{c}}$ & $0.198^{\mathrm{c}}$ & $0.131^{\mathrm{bc}}$ \\
SOD in RBCs & $24.81 \pm$ & $16.02 \pm$ & $19.57 \pm$ & $18.97 \pm$ & $17.44 \pm$ & $17.88 \pm$ \\
& $0.906^{\mathrm{a}}$ & $0.907^{\mathrm{b}}$ & $0.795^{\mathrm{c}}$ & $0.802^{\mathrm{bc}}$ & $0.521^{\mathrm{bc}}$ & $0.701^{\mathrm{bc}}$ \\
\hline
\end{tabular}

Values are mean \pm SEM for $\mathrm{n}=8$. Similar superscript alphabets in row indicate non-significant differences $(\mathrm{P} \geq 0.05)$ at $90^{\text {th }}$ day. Dissimilar superscript alphabets in row indicate significant differences $(\mathrm{P}<0.05)$ at $90^{\text {th }}$ day. * in liver; ** in RBC; GPx, glutathione peroxidase; SOD, superoxide dismutase.

Table 5: Antioxidative damaged products (TBARS and PCs) activity in liver and plasma.

\begin{tabular}{|l|c|c|c|c|c|c|}
\hline $\begin{array}{l}\text { Products } \\
\text { (nmoles mg-1) }\end{array}$ & Control & CED & $\begin{array}{c}\text { CED+ } \\
\text { Goat }\end{array}$ & $\begin{array}{c}\text { CED+ } \\
\text { Camel }\end{array}$ & $\begin{array}{c}\text { CED+ } \\
\text { Cow }\end{array}$ & $\begin{array}{c}\text { CED+ } \\
\text { Buffalo }\end{array}$ \\
\hline TBARS* & $0.334 \pm$ & $1.131 \pm$ & $0.405 \pm$ & $0.538 \pm$ & $0.700 \pm$ & $0.896 \pm$ \\
& $0.011 \mathrm{a}$ & $0.046 \mathrm{~b}$ & $0.026 \mathrm{ac}$ & $0.021 \mathrm{c}$ & $0.027 \mathrm{~d}$ & $0.051 \mathrm{e}$ \\
PCs* & $2.792 \pm$ & $10.810 \pm$ & $5.089 \pm$ & $6.294 \pm$ & $7.498 \pm$ & $10.860 \pm$ \\
& $0.089 \mathrm{a}$ & $0.353 \mathrm{~b}$ & $0.329 \mathrm{c}$ & $0.185 \mathrm{ce}$ & $0.253 \mathrm{e}$ & $0.572 \mathrm{~b}$ \\
TBARS** & $0.168 \pm$ & $0.292 \pm$ & $0.218 \pm$ & $0.219 \pm$ & $0.226 \pm$ & $0.244 \pm$ \\
& $0.004 \mathrm{a}$ & $0.008 \mathrm{~b}$ & $0.006 \mathrm{c}$ & $0.005 \mathrm{c}$ & $0.008 \mathrm{c}$ & $0.007 \mathrm{c}$ \\
PCs** & $0.841 \pm$ & $1.934 \pm$ & $1.412 \pm$ & $1.526 \pm$ & $1.562 \pm$ & $1.639 \pm$ \\
& $0.043 \mathrm{a}$ & $0.075 \mathrm{~b}$ & $0.065 \mathrm{c}$ & $0.050 \mathrm{c}$ & $0.029 \mathrm{c}$ & $0.069 \mathrm{c}$ \\
\hline
\end{tabular}

Values are mean \pm SEM for $\mathrm{n}=8$. Similar superscript alphabets in row indicate non-significant differences $(\mathrm{P} \geq 0.05)$ at $90^{\text {th }}$ day. Dissimilar superscript alphabets in row indicate significant differences $(\mathrm{P}<0.05)$ at $90^{\text {th }}$ day. $*$ in liver; $* *$ in plasma 
Cardiovascular disease and obesity are more prevalent in society now than ever before. These are related to lifestyle, which is changing very fast in society. Consumption of fast food and decrease in exercise are major factors. For their treatment, numerous drug regimens are available in the market but these may cause one or the other side effects. Dietary food habits are linked with occurrence of disease as well as overcoming ill effects of disease. The results presented suggest that milk has inherent property to lower TC, TG, VLDL-C, LDL-C and enhance HDL-C and thereby improves AI. Milk also assists in enhanced excretion of cholesterol through feces and reduced deposition of cholesterol in aorta and liver.

Free oxygen radicals and insufficient antioxidant enzymes have been implicated in the pathogenesis of hypercholesterolemia (Nasar et al., 2015). Oxidized LDL is major causative agent for oxidative stress in hypercholesterolemic patients (Nasar et al., 2015). Milk not only reduces enhanced level of plasma LDL but also exhibits anti-oxidative activity. Thus, milk has potential to lower the formation of oxidized LDL and mitigate oxidative stress. Anti-oxidant activity of milk is derived from anti-oxidants present in milk as well as its ability to enhance the level of expression of anti-oxidative enzymes viz. catalase, GPx and SOD in vivo. Milk from different species differs in composition as well as in level of antioxidants. For example, camel milk contains high concentrations of vitamins A, B2, C and E and is rich in minerals such as calcium, iron, magnesium, copper, zinc, potassium (Al-Humaid et al., 2010). Magnesium protects the cell against ROS and assists in absorption of vitamins B, C and E which functions as anti-oxidants. In comparison to bovine milk, camel milk exhibits about three fold anti-oxidant activity (Chen et al., 2003) and goat milk from Prisca breed has 50\% more TAC activity (Simos et al., 2011)measured in vitro. Anti-oxidant activity is dependent onanti-oxidants present in milk. Selenium content in goat milk is about $41 \%$ higher than in cow milk (Debski et al., 1987) and is component of GPx, an antioxidant enzyme. Our results do suggest that extent of expression of anti-oxidant enzymes on milk feeding is also dependent on species of lactating animal. For example, goat milk-feeding led to increase in vivo production of catalase, GPx and SOD in liver as well as in RBC. Camel milk resulted in similar trend except SOD in RBC. Cow or buffalo milk in comparison to goat and camel milk were poor in effectiveness in expressing antioxidant enzymes (Table 4) in vivo.

Oxidative stress may also cause oxidation of protein and results in the formation of protein carbonyls. Since many of proteins exhibits catalytic properties, the effect of oxidative damage to protein will be many folds in comparison to stoichiometric relationship in lipid damage. The altered structure of enzymes involved in cholesterol metabolism will affect cholesterol homeostasis. Except PCs in liver on feeding of buffalo milk, all milks reduce enhanced level of PCs in liver as well as in plasma (Table 5). Production of TBARS is also lowered in liver and plasma on milk feeding (Table 5).

Cholesterol deposition in aorta is indicative of prolong hypercholesterolemic conditions (Ung-Kyu et al., 2010). Milk helps in reduction in cholesterol deposition in aorta and the effect is not species specific. This suggests that chemical ingredients common in all milk might be involved in retardation of deposition of cholesterol in aorta. Cholesterol excretion in feces is enhanced on milk-feeding and comparatively this property is more expressed in camel \& goat milk over cow or buffalo milk.

Milk assists in maintaining cholesterol homeostasis in hypercholesterolemic rats by enhancing excretion of cholesterol through feces, lowering of cholesterol deposition in liver and aorta. Milk also reduces oxidative stress by enhancing production of anti-oxidant enzymes in vivo which is order of goat $>$ camel $>$ cow $>$ buffalo. Milk-feeding resulted in lower production of 
TBARS and PCs. Effectiveness of goat and camel milk was similar and was better than cow milk. It appears that anti-oxidant property of milk governs maintenance of cholesterol homeostasis.

\section{Acknowledgement}

The authors would like to thank Indian Council of Agricultural Research (ICAR) for providing the funding for this research work.

\section{Conflict of Interest}

The authors report no conflict of interest in this work.

\section{References}

1. Aebi, H. (1984). Catalase in vitro. Methods Enzymol.105:121-126.

2. Aggarwal, R.A. and Kansal, V.K. (1992). Effect of skim milk on progression of atherosclerosis in cholesterol-fed rabbits. Indian Journal of Medical Research. 96: 5359.

3. Agrawal, R.P., Budania, S., Sharma, P., Gupta, R., Kochar, D.K., Panwar, R.B. and Sahani, M.S. (2007). Zero prevalence of diabetes in camel milk consuming Raica community of north-west Rajasthan, India. Diabetes Research and Clinical Practice, 76:290-296.

4. Al-Awadi, F.M. and Srikumar, T.S. (2001). Trace elements and their distribution in protein fractions of camel milk in comparison to other commonly consumed milks. Journal of Diary Research, 68(3):463-469.

5. Al-Ayadhi, L.Y. and Elamin, N.E. (2013). Camel Milk as a Potential Therapy as an Antioxidant in Autism Spectrum Disorder (ASD). Journal of EvidenceBased Complementary and Alternative Medicine, doi: 10.1155/2013/602834.

6. Al-Humaid, A.I., Mousa, H.M., ElMergawi, R.A. and Abdel-Salam, A.M. (2010). Chemical composition and antioxidant activity of dates and datescamel-milk mixtures as a protective meal against lipid peroxidation in rats. American Journal of Food Technology, 5:22-30.

7. AOAC (1990). Official methods of analysis. $16^{\text {th }}$ Edn. Association of Official Analytical Chemists Washington, DC.
8. Bejma, J. and Ji, L.L. (1999). Aging and acute exercise enhance free radical generation in rat skeletal muscle Journal of Applied Physiology, 87:465-470.

9. Bravo, E., Flora, L., Cantafora, A., De Luca, V., Tripodi, M., Avella, M. and Botham, K.M. (1998). The influence of dietary saturated and unsaturated fat on hepatic cholesterol metabolism and the biliary excretion of chylomicron cholesterolin the rat. Biochimica et Biophysica Acta, 1390(2):134-148.

10. Chen, J., Lindmark-Mansson, H., Gorton, L. and Akesson, D. (2003). Antioxidant capacity of bovine milk as assayed by spectrophotometric and amperometric methods. International Dairy Journal, 13: 927-935.

11. Conesa, C., Sanchez, L., Rota, C., Perez, M.D., Calvo, M., Farnaud, S. and Evans, R.W. (2008). Isolation of lactoferrin from milk of different species: Calorimetric and antimicrobial studies. Comparative Biochemistry \& Physiology, 150:131-139.

12. Debski, B., Picciano, M.F. and Milner, J.A. (1987). Selenium content and distribution of human and cow and goat milk. Journal of Nutrition, 117(6):1091-1097.

13. Drabkin, D.L. (1950). Spectrophotometric studies. XV. Hydration of macro sized crystals of human hemoglobin and osmotic concentrations in red cells. Journal of Biological Chemistry, 185:231-245.

14. El-Agamy, E.I., Nawar, M., Shamsia, S.M., Awad, S. and Haenlein, G.F.W. (2009). Are camel milk proteins convenient to the nutrition of cow milk allergic children? Small Ruminant Research, 82:1-6.

15. Folch, J.M.L. and Slane-Stanley, G.H. (1957). A simple method for the isolation and purification of total lipids from animal tissues. Journal of Biological Chemistry, 226:497-506.

16. Friedewald, W.T., Levy, R.I. and Fredrickson, D.S. (1972). Estimation of the concentration of low-density lipoprotein cholesterol in plasma, without use of the preparative ultra-centrifuge. Clinical Chemistry, 18: 499-502.

17. Gobba, C.D., Espejo-Carpio, F.J., Skibsted, L.H. and Otte, J. (2014). Antioxidant 
Milk improves cholesterol homoeostasis by protecting liver against oxidative damage in hypercholesterolemic rats

peptides from goat milk protein fraction hydrolysed by two commercial proteases. International Dairy Journal, 39: 28-40.

18. Khay, E.O., Idaomar, M., Castro, L.M.P., Bernardez, P.F., Senhaji, N.S. and Abrini, J. (2011). Antimicrobial activities of the bacteriocin-like substances produced by lactic acid bacteria isolated from Moroccan dromedary milk. African Journal of Biotechnology, 10(51):10447-10455.

19. Kotb-El-Sayed, M.I., Al-Shoeibi, Z.Y., EIGhany, A.A.A. and Atef, Z.A. (2011). Effects of Camel's Milk as a Vehicle for Insulin on Glycaemic Control and Lipid Profile in Type 1 Diabetics. American Journal of Biochemistry and Biotechnology, 7(4):179-189.

20. Levine, R.L., Garland, D., Oliver, C.N., Amici, A., Climent, I., Lenz, A.G., Ahn, B.W., Shaltiel, S. and Stadtman, E. (1990). Determination of carbonyl content in oxidatively modified modified proteins. Methods in Enzymology, 186:464-478.

21. Lowry, O.H., Rosebrough, N.J., Farr, A.L. and Randall, R.J. (1951). Protein measurement with folin phenol reagent. Journal of Biological Chemistry, 193:265275.

22. Marklund, S. and Marklund, G. (1974). Involvement of superoxide dismutase anion radical radical in autooxidation of pyrogallol and a convenient assay for superoxide dismutase. European Journal of Biochemistry, 42:469-474.

23. Meena, S., Rajput, Y.S. and Sharma, R. (2014). Comparative fat digestibility of goat, camel, cow and buffalo milk. International Dairy Journal, 35(2):153156.
24. Nasar, M.A., Gupta, R.P. and Subhani, T.F. (2015). Oxidative stress in hypercholesterolemic patients and antioxidant status of fluvastatin. Indian Journal of Medical Research \& Pharmaceutical Science, 2(1): 21-28.

25. Nichans, W.G. and Samuelson, D. (1968). Formation of malondialdehyde from phospholipid arachidonate during microsomal lipid peroxidation. European Journal of Biochemistry, 6:126-130.

26. Nikkah, A. (2011). Science of Camel and Yak Milks: Human Nutrition and Health Perspectives. Food and Nutrition Sciences, 2: 667-673.

27. Paglia, D.E. and Valentine, W.N. (1967). Studies on quantitative and qualitative characterization of erythrocyte glutathione peroxidase. Journal of Clinical Chemistry and Laboratory Medicine, 70:158-169.

28. Shabo, Y. and Yagil, R. (2005). Behavioral improvement of autistic children following drinking camel milk. In: Treating Persons with Brain Damage. 4th National Conference. Tel Aviv, Israel.

29. Simos, Y., Metsios, A., Verginadis, I., D'Alessandro, A.G., Loiudice, P., Jirillo, E., Charalampidis, P., Kouimanis, V., Boulaka, A., Martemucci, G. and Karkabounas, S. (2011). Anitioxidant and anti-platelet properties of milk from goat, donkey and cow: An in vitro, ex vivo and in vivo study. International Dairy Journal, 21: 901-906.

30. Ung-Kyu, C., Ok-Hwan, L., Joo, H.Y., Chang-Won, C., Young, K.R., Seong-Il, L., Young-Chan, K. (2010). Hypolipidemic and Antioxidant Effects of Dandelion (Taraxacum officinale) Root and Leaf on Cholesterol-Fed Rabbits. International Journal of Molecular Science, 11:67-68.

\begin{tabular}{|ll}
\hline Received & : February, 2020 \\
Revised & : April, 2020 \\
Published & : June, 2020
\end{tabular}

